\title{
Aplikasi Chatbot untuk Layanan Informasi dan Akademik Kampus Berbasis Artificial Intelligence Markup Language (AIML)
}

\author{
Guntoro $^{1}$, Loneli Costaner ${ }^{2}$, Lisnawita ${ }^{3}$ \\ ${ }^{1,2,3}$ Program Studi Teknik Informatika Fakultas Ilmu Komputer Universitas Lancang Kuning \\ ${ }^{1,2,3}$ Jl. Yos Sudarso KM. 8 Rumbai, Pekanbaru, Riau, telp. 08117532015 \\ e-mail: ${ }^{1}$ guntoro@unilak.ac.id, ${ }^{2}$ lonelicostaner@unilak.ac.id, ${ }^{3}$ lisnawita@unilak.com
}

\begin{abstract}
Abstrak
Saat ini sebagian besar universitas menggunakan sistem informasi web untuk menyampaikan informasi terkait informasi pendaftaran mahasiswa, akademik, beasiswa, biaya pendidikan dan lain-lain. Dalam hal pelayanan pendidikan, tentunya universitas perlu memberikan layanan yang terbaik, agar para civitas akademik kampus, masyarakat mendapatkan kepuasan terhadap layanan yang diberikan. Penelitian ini adalah mengembangkan aplikasi chatbot yang dapat digunakan sebagai layanan informasi kampus dan akademik bagi masyarakat umum maupun bagi civitas akademik kampus Universitas Lancang Kuning Adapun tahapan dalam pengembangan aplikasi chatbot ini diantaranya adalah pengumpulan kebutuhan, desain, membuat prototype, evaluasi dan perbaikan. Adapun metode yang digunakan untuk pembelajaran chatbot menggunakan Artificial Markup Language (AIML). Knowledge dari aplikasi chatbot ini adalah alamat kampus, syarat pendaftaran, langkah pendaftaran, program studi, jalur kuliah, berapa biasa kuliah dan cara daftar. Berdasarkan hasil pengujian yang telah dilakukan dengan metode whitebox dan blackbox, bahwa aplikasi chatbot dapat berjalan dengan baik sebesar 100\%. Sedangkan pengujian menggunakan UAT sebesar 95\%. Hal tersebut menunjukkan bahwa aplikasi chatbot mampu menjawab pertanyaan-pertanyaan yang diajukan, sesuai dengan pengetahuan yang telah diberikan sebelumnya.
\end{abstract}

Kata kunci: Akademik, AIML, Chatbot.

\begin{abstract}
Currently, most universities use web-based information systems to provide information on student enrollment, academics, scholarships, fees, and so on. As far as education services are concerned, of course, universities need to offer the best service to ensure that the campus learning community is happy with the services offered. The goal of this research is to build a chatbot application that can use as a campus and academic information service for the general public and the academic community of Universitas Lancang Kuning. The phases in the development of this chatbot framework include gathering needs, designing, creating prototypes, testing and improving. The tool used to learn the chatbot uses the Artificial Markup Language (AIML). Knowledge from the chatbot application is the campus address, registration requirements, registration steps, study program, course path, how many lectures are used and how to register. Based on the results of the tests carried out using the Whitebox and BlackBox methods, the chatbot framework will run 100\%. While testing using UAT is $95 \%$. The Chatbot framework can answer the questions that have been posed, based on the information that has been previously given.
\end{abstract}

Keywords: Academic, AIML, Chatbot

\section{Pendahuluan}

Saat ini, sebagian besar universitas menggunakan sistem informasi web untuk menyampaikan informasi terkait informasi pendaftaran mahasiswa, akademik, beasiswa, biaya 
pendidikan dan lain-lain. Dalam hal pelayanan pendidikan, tentunya universitas perlu memberikan layanan yang terbaik, agar para civitas akademik kampus, masyarakat mendapatkan kepuasan terhadap layanan yang diberikan [1]. Untuk mendapatkan kepuasan dari masyarakat maupun civitas akademik kampus selain dari kualitas pendidikan dan bangunan, universitas juga harus memberikan layanan konsultasi dan informasi bagi masyarakat dan civitas akademik kampus. Penggunanaan sistem layanan informasi berbasis web dan media sosial adalah salah satu fasilitas yang sering digunakan untuk memenuhi kebutuhan informasi.

Seiring dengan meningkatnya perkembangan teknologi web, banyak inovasi-inovasi terbaru dalam pengembangan website [2]. Ada berbagai jenis layanan yang digunakan untuk melayani kebutuhan akademik kampus seperti menggunakan telepon, chating dan lain-lain. Semua jenis layanan ini bertujuan untuk berkomunasi antara pihak kampus dengan masyarakat luar kampus maupun dalam kampus [3].

Pesatnya perkembangan teknologi informasi berbasis komputer telah membuat banyak perubahan dalam kehidupan manusia, salah satunya adalah teknologi Artificial Intelligence (AI) [4]. Dengan teknologi AI, komputer dapat melakukan tugas-tugas tertentu sama seperti yang dilakukan oleh manusia, salah satunya adalah chatbot [5]. Chatbot adalah sebuah sistem yang mengadopsi pengetahuan seperti sifat manusia [6]. Sehigga komputer dapat memiliki kemampuan dalam memahami percakapan dengan pengguna dengan menggunakan bahasa alami [7]. Pemanfaatan teknologi chatbot saat ini sudah banyak digunakan diberbagai sektor, misalnya pendidikan, e-commerce, pemerintahan, perusahaan maupun public figure. Teknologi chatbot sangat bermanfaat ketika diterapkan di dunia pendidikan, khususnya universitas, hal ini bertujuan untuk melayani atau menjawab pertanyaan-pertanyaan dari mahasiswa maupun calon mahasiswa. Dengan adanya teknologi chatbot ini juga dapat meningkatkan kualitas pelayanan maupun menambah daya tarik bagi calon mahasiswa untuk mendaftar di universitas. Salah satu metode yang digunakan untuk menerapkan aplikasi chatbot adalah Artificial Intelligence Markup Language (AIML)

Artificial Intelligence Markup Language (AIML) merupakan subset dari Extensible Markup Language (XML) [8] [9], yang berfungsi untuk membuat sistem input pertanyaan balasan berbasis pengetahuan. Pada AIML tag dapat diartikan berbeda dengan fungsi masingmasing [10]. Konsep dari AIML berupa template matching yaitu dengan mencocokan inputan pengguna dengan pattern yang telah ditentukan sebelumnya [11] .

Pada penelitian [3], mengembangkan aplikasi chatbot menggunakan pendekatan machine learning, yang bertujuan untuk informasi penerimaan calon mahasiswa baru di Universitas Dian Nuswantoro (UDINUS). Penelitian [1], mengembangkan aplikasi chatbot dengan menggunakan metode Articial Intelligence Markup Language (AIML dan Latent Semantic Analysis (LSA). Chatbot yang dikembangkan digunakan untuk menjawab pertanyaan-pertanyaan dari para mahasiswa di perguruan tinggi. Dalam penelitian [12] melakukan penelitian pengembangan chatbot menggunakan model Squence-to-Squence yang digunakan untuk informasi penerimaan mahasiswa di Telkom University. Penelitian mengembangkan chatbot menggunakan aplikasi whatsapp. Penelitian [13], mengembangkan aplikasi chatbot interaktif berbasis web dengan mengguankan bahasa pemrograman PHP. Penelitian [5] mengembangkan aplikasi chatbot kampus menggunakan Artificial Intelligence Markup Language dalam bahasa myanmar. Penelitian [14] mengembangkan aplikasi chabot berbasis mobile yang digunakan untuk konseling HIV/AIDS menggunakan metode AIML. Penelitian [15] mengembangkan chatbot yang digunakan untuk asisten e-commerce dengan metode AIML.

Berdasarkan penelitian yang telah dilakukan sebelumnya, ada banyak chatbot yang dikembangkan dengan menggunakan bahasa inggris maupun bahasa lainnya dengan metode yang sangat modern dan menggunakan aplikasi yang aplikasi seperti Whatsapp, Line, Telegram dan lain-lain, tetapi dengan menggunakan bahasa indonesia masih sedikit, khususnya chabot untuk melayani informasi kampus dan akademik. Pada penelitian ini kami ingin mengusulkan pengembangan aplikasi chatbot yang sederhana, sehingga dapat digunakan sebagai layanan informasi kampus dan akademik bagi masyarakat umum maupun bagi civitas akademik kampus Universitas Lancang Kuning menggunakan metode Artificial Intelligence Markup Language 
(AIML) [11]. Adapun bahasa yang digunakan dalam percakapan chatbot ini menggunakan bahasa indonesia, yaitu bahasa resmi percakapan sehari-hari.

\section{Metode Penelitian}

Adapun tahapan penelitian yang akan dilakukan yaitu analisis kebutuhan, desain, implementasi dan pengujian. Adapun tahapannya terlihat pada Gambar 1.

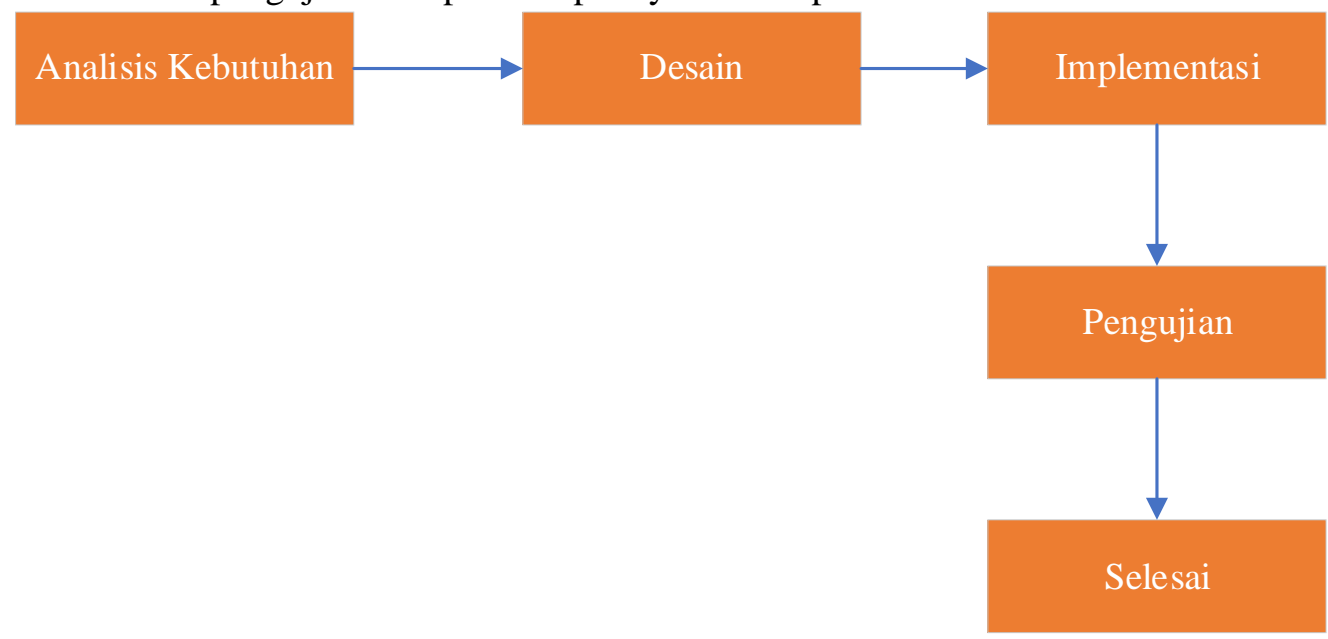

Gambar1. Metode Penelitian

\subsection{Analisis Kebutuhan}

Pada langkah analis kebutuhan merupakan tahap pengumpulan data dan informasi yang dibutuhkan dalam penelitian. Adapun pengumpulan kebutuhan dilakukan dengan melibatkan bagian akademik penyedia informasi layanan. Pengumpulan kebutuhan juga dilakukan dengan mencari literature terkait dengan bagaimana pengembangan chatbot dengan menggunakan AIML.

\subsection{Desain}

Sebelum dilakukan pembuatan prototype, tahapan yang dilakukan terlebih dahulu adalah dengan melakukan perancangan sistem dengan menggunakan flowchart, use case diagram, untuk menggambarkan fungsi-fungsi apa saja yang ada pada aplikasi chatbot. Aplikasi yang digunakan untuk merancang prototype chabot adalah Microsoft Visio.

\subsection{Implementasi}

Pada tahap ini dilakukan membuat prototype aplikasi chatbot dari perancangan yang sudah rancang sebelumnya. Adapun dalam pengembangan aplikasi chatbot ini menggunakan tools yaitu:

1. Hardware
a. Laptop Lenovo Thinkpad T430
b. Prosesor i5
c. SSD 240GB
d. Memory: $8 \mathrm{~GB}$

2. Software
a. Sistem operasi Linux Ubuntu 14.0
b. Editor Geany
c. Bahasa Pemrograman Python versi 3.5
d. Library Flask versi 0.12.3
e. Library AIML 0.8.6

\subsection{Pengujian}

Setelah prototype apliasi chatbot dibangun, maka langkah selanjutnya adalah melakukan evaluasi, apakah aplikasi dapat berjalan dengan baik atau tidak. Metode evaluasi yang digunakan adalah metode blackbox dan whitebox. Adapun pertanyaan yang digunakan untuk menguji blabox adalah seperti terlihat pada tabel 
Tabel 1 Rencangan Pengujian Blackbox

\begin{tabular}{|c|c|c|c|}
\hline No & Pertanyaan & Hasil yang diharapkan & Hasil \\
\hline 1 & Alamat Kampus & Jl. Yos Sudarso KM. 8 Pekanbaru - Riau & ? \\
\hline 2 & Syarat Pendaftaran & $\begin{array}{l}\text { https://www.unilak.ac.id/page/detail/syarat- } \\
\text { pendaftaran }\end{array}$ & $?$ \\
\hline 3 & Langkah Pendaftaran & $\begin{array}{l}\text { https://www.unilak.ac.id/page/detail/langkah- } \\
\text { pendaftaran }\end{array}$ & $?$ \\
\hline 4 & Program Studi & $\begin{array}{l}\text { Manajemen, Akuntansi, Ilmu Hukum, Ilmu } \\
\text { Administrasi Negara, Ilmu Perpustakaan, Sastra } \\
\text { Indonesia, Sastra Inggris, Sastra Daerah, Pendidikan } \\
\text { Biologi, Pendidikan Guru, Pendidikan Anak Usia Dini, } \\
\text { Pendidikan Bahasa Inggris, Teknik Informaka, Sistem } \\
\text { Informasi, Agribisnis, Agroteknologi, Teknik Elektro, } \\
\text { Teknik Sipil, Arsitektur, Kehutanan, Manajemen, Ilmu } \\
\text { Hukum S2 } \\
\text { https://www.unilak.ac.id/page/detail/pilihan-program- } \\
\text { studi }\end{array}$ & $?$ \\
\hline 5 & Jalur Kuliah & $\begin{array}{l}\text { 1. Jalur Mandiri, 2. Jalur Prestasi, 3. Jalur Pindahan, } 4 . \\
\text { Jalur Strata-S2 }\end{array}$ & $?$ \\
\hline 6 & Berapa Biaya Daftar & $\begin{array}{l}\text { Biaya pendaftaran mahasiswa baru UNILAK Rp. } \\
\text { 300.000, atau kunjungi } \\
\text { https://unilak.ac.id/page/detail/jalur-mandiri-s1 }\end{array}$ & $?$ \\
\hline 7 & Cara Daftar & https://www.unilak.ac.id/daftar_online & $?$ \\
\hline
\end{tabular}

\section{Hasil dan Pembahasan}

3.1 Analisa Sistem Lama

Adapun sistem lama yang sedang berjalan di Universitas Lancang Kuning adalah calon mahasiswa, mahasiswa atau masyarakat umum, ketika ingin berkonsultasi terkait dengan informasi pendaftaran mahasiswa baru, biaya spp, informasi program studi, serta informasi akademik lainnya, maka harus menelpon, e-mail, mengakses website Universitas Lancang Kuning, dan chating menggunakan whatsapp. Dengan adanya sistem yang ada sekarang, terkadang informasi yang didapatkan membutuhkan waktu yang lama, sehingga menyulitkan bagi calon mahasiswa, terutama ketika ingin mendapatkan informasi pendaftaran. Oleh karena itu dibutuhkan sistem yang dapat menjawab pertanyaan dari calon mahasiswa dan secara otomatis. Adapun alur sistem yang sedang berjalan adalah terlihat pada gambar 2. sedang berjalan.

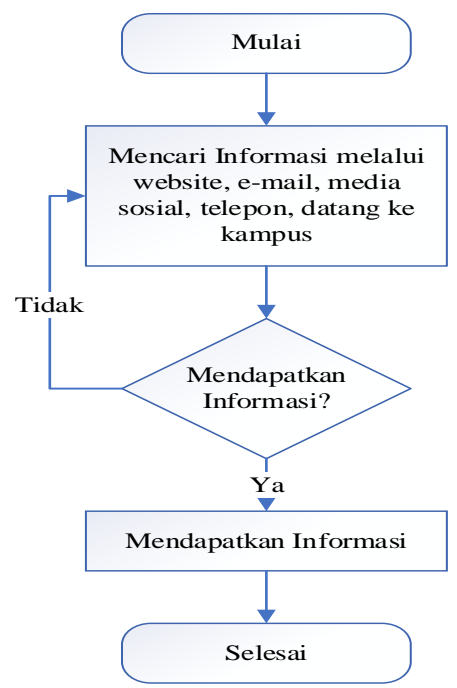

Gambar 2 Sistem Sedang Berjalan 


\subsection{Sistem Baru}

Sistem baru yang akan dirancang adalah membuatkan aplikasi chatbot menggunakan metode AIML. Aplikasi dirancang dalam bentuk halaman chating yang digunakan untuk pengguna dalam mengajukan pertanyaan dan mesin chatbot akan memberikan jawaban sesuai dengan pengetahuan yang telah diberikan. Perancangannya adalah alur aplikasi chatbot, perancangan tampilan. Adapun alur aplikasi chatbot yang diusulkan seperti terlihat pada gambar 3.

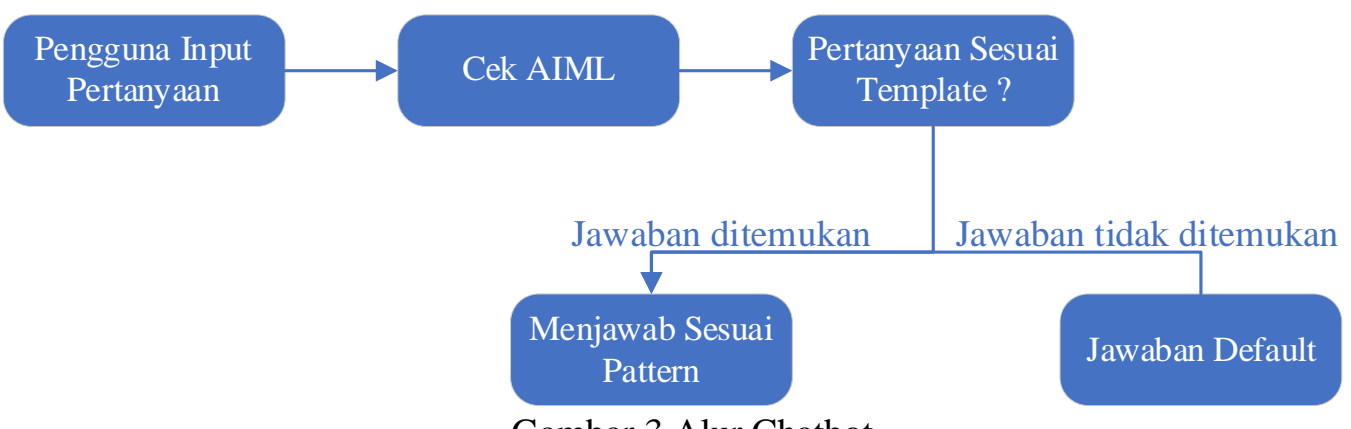

Pada gambar 3 adalah alur aplikasi chatbot yang akan dikembangkan. Langkah 1 pengguna melakukan input pertanyaan, langkah 2 pertanyaan akan diproses oleh metode AIML, lalu akan di cek apakah sesuai dengan template pengetahuan yang telah diberikan atau tidak, langkah 4 jika jawaban ditemukan maka chatbot akan menjawab sesuai dengan pattern, dan jika jawaban tidak ditemukan maka chatbot akan menjawab sesuai dengan jawaban default sistem.

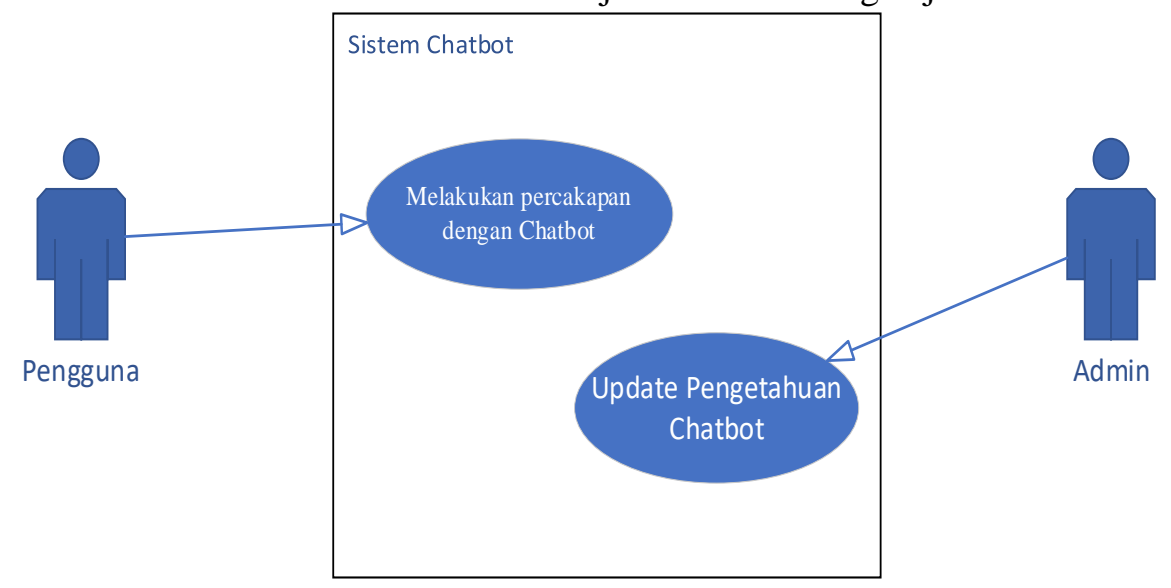

Gambar 4 Use Case Diagram

Pada gambar 4 adalah use case diagram yang menggambarkan sistem chatbot yang akan dibangun. Pengguna dapat melakukan percakapan dengan aplikasi chatbot, sedangkan admin dapat melakukan update pengetahuan chatbot. Update pengetahuan langsung ke dalam rule program AIML. Adapun rule (pengetahuan) yang digunakan pada aplikasi chatbot adalah seperti terlihat pada Tabel 2.

\begin{tabular}{lll} 
& \multicolumn{1}{c}{ Tabel 2 Pengetahuan Chatbot } \\
\hline No & \multicolumn{1}{c}{ Pattern } & \multicolumn{1}{c}{ Template } \\
\hline 1 & $*$ & Jl. Yos Sudarso KM. 8 Pekanbaru - Riau \\
\hline 2 & Alamat & $\underline{\text { https://www.unilak.ac.id/page/detail/syarat- }}$ \\
\hline 3 & Syarat Pendaftaran & $\underline{\text { hendaftaran }}$ \\
\hline 4 & Langkah Pendaftaran & pendaftaran \\
\hline 5 & Program Studi & $\begin{array}{l}\text { Manajemen, Akuntansi, Ilmu Hukum, Ilmu } \\
\text { Administrasi Negara, Ilmu Perpustakaan, Sastra }\end{array}$ \\
\hline
\end{tabular}




\begin{tabular}{lll}
\hline No & Pattern & \multicolumn{1}{c}{ Template } \\
& & Indonesia, Sastra Inggris, Sastra Daerah, \\
& & Pendidikan Biologi, Pendidikan Guru, \\
& Pendidikan Anak Usia Dini, Pendidikan Bahasa \\
& Inggris, Teknik Informaka, Sistem Informasi, \\
& Agribisnis, Agroteknologi, Teknik Elektro, \\
& Teknik Sipil, Arsitektur, Kehutanan, Manajemen, \\
& & Ilmu Hukum S2 \\
& & https://www.unilak.ac.id/page/detail/pilihan- \\
& & program-studi \\
\hline 6 & Jalur Kuliah & Pindahan, 4. Jalur Strata-S2 \\
\hline 7 & Biaya Kuliah & $\underline{\text { https://www.unilak.ac.id/page/detail/jalur- }}$ \\
& & mandiri-s1 \\
\hline 8 & Daftar Online & https://www.unilak.ac.id/daftar_online \\
\hline
\end{tabular}

\subsection{Perancangan Antarmuka}

Pada gambar 5 adalah perancangan antarmuka aplikasi chatbot yang dikembangkan. Antar muka chatbot yang dikembangkan terdiri dari nama chabot, form input pertanyaan, halaman informasi pertanyaan dan jawaban chatbot serta tombol bersihkan chat dan tombol kirim.

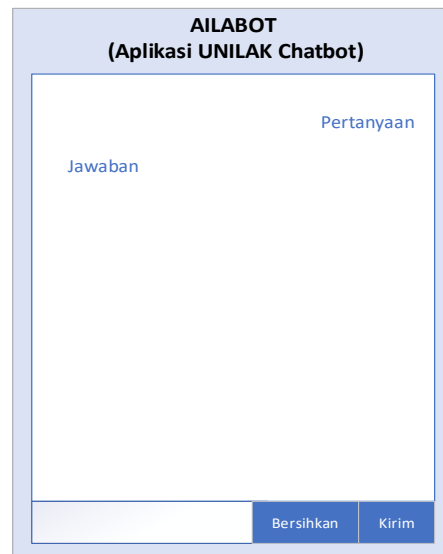

\subsection{Implementasi Sistem}

Gambar 5 Perancangan Antarmuka Chatbot

Setelah tahap perancangan sistem, selanjutnya perancangan dituangkan ke dalam bahasa pemrograman dan dibuat antarmuka chatbot. Adapun aplikasi chatbot yang dibangun terlihat pada gambar 6.

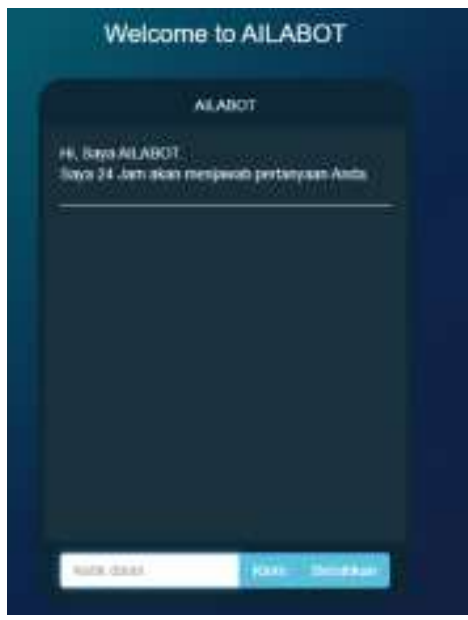

Gambar 6 Antarmuka Chatbot 


\subsection{Pengujian}

\subsubsection{Pengujian Whitebox dan Blackbox}

Pada tahap ini dilakukan pengujian whitebox dan blackbox. Pengujian whitebox menggunakan pengujian unit serta integritas. Sedangkan pengujian blackbox menggunakan pengujian validasi dan pengetahuan. Adapun pengujian validasi seperti terlihat pada tabel 3 .

Tabel 3 Pengujian Validasi

\begin{tabular}{llll}
\hline No & \multicolumn{1}{c}{ Pattern } & \multicolumn{1}{c}{ Template } & Hasil \\
\hline 1 & $\begin{array}{l}\text { Alamat } \\
\text { Kampus }\end{array}$ & Jl. Yos Sudarso KM. 8 Pekanbaru - Riau & Valid \\
\hline 2 & $\begin{array}{l}\text { Syarat } \\
\text { Pendaftaran }\end{array}$ & $\begin{array}{l}\text { https://www.unilak.ac.id/page/detail/syarat- } \\
\text { pendaftaran }\end{array}$ & Valid \\
\hline 3 & $\begin{array}{l}\text { Langkah } \\
\text { Pendaftaran }\end{array}$ & $\begin{array}{l}\text { https://www.unilak.ac.id/page/detail/langkah- } \\
\text { pendaftaran }\end{array}$ & Valid \\
\hline 4 & $\begin{array}{l}\text { Program } \\
\text { Studi }\end{array}$ & $\begin{array}{l}\text { Manajemen, Akuntansi, Ilmu Hukum, Ilmu } \\
\text { Administrasi Negara, Ilmu Perpustakaan, }\end{array}$ & Valid \\
& & Sastra Indonesia, Sastra Inggris, Sastra & \\
& & Daerah, Pendidikan Biologi, Pendidikan & \\
& & Guru, Pendidikan Anak Usia Dini, & \\
& & Pendidikan Bahasa Inggris, Teknik & \\
& & Informaka, Sistem Informasi, Agribisnis, & \\
& & Agroteknologi, Teknik Elektro, Teknik Sipil, & \\
& & Arsitektur, Kehutanan, Manajemen, Ilmu & \\
& & Hukum S2 & \\
& & https://www.unilak.ac.id/page/detail/pilihan- & \\
& & program-studi & \\
\hline 5 & Jalur & 1. Jalur Mandiri, 2. Jalur Prestasi, 3. Jalur & Valid \\
& Kuliah & Pindahan, 4. Jalur Strata-S2 & \\
\hline 6 & Berapa & Biaya pendaftaran mahasiswa baru UNILAK & Valid \\
& Biaya & Rp. 300.000, atau kunjungi \\
& Daftar & https://unilak.ac.id/page/detail/jalur-mandiri- & \\
& & s1 & \\
\hline 7 & Cara Daftar & https://www.unilak.ac.id/daftar_online & Valid \\
& & &
\end{tabular}

Tabel 4 Pengujian Pengetahuan Chatbot

\section{Prosedur}

Menjalankan sistem dengan inputan tertentu

Hasil yang diharapkan

Sistem dapat merespon inputan sesuai dengan pengetahuan yang telah diberikan

Hasil

Sistem dapat merespon inputan sesuai dengan pengetahuan yang telah diberikan

Status Valid 


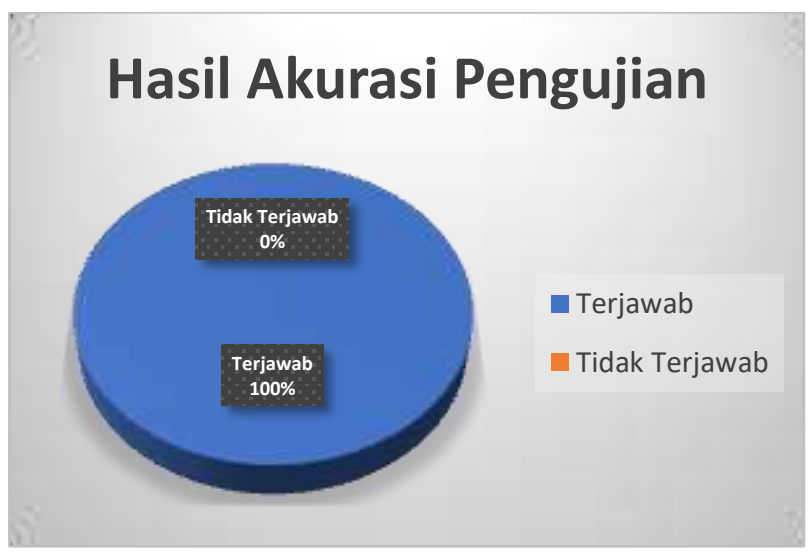

Gambar 7 Hasil Akurasi Pengujian

Berdasarkan tabel 4 dan gambar 7 bahwa pengujian yang dilakukan menggunakan metode whitebox dan blackbox didapat nilai sebesar 100\%. Hal tersebut menunjukkan bahwa aplikasi chatbot yang dikembangkan menggunakan metode Artificial Intelligence Markup Language (AIML) mampu menjawab pertanyaan-pertanyaan, berdasarkan pengetahuan yang telah diberikan, semakin banyak pengetahuan yang diberikan maka chatbot dapat menjawab pertanyaan-pertanyaan lebih luas.

\subsubsection{Pengujian UAT (User Aceptance Test)}

Pengujian UAT adalah suatu proses pengujian oleh pengguna yang dimaksudkan untuk menghasilkan dokumen yang dijadikan bukti bahwa sistem yang dikembangkan dapat diterima atau tidaknya oleh pengguna, apabila hasil pengujian sudah bisa dianggap memenui kebutuhan dari pengguna maka aplikasi dapat diterapkan.

Pengujian dengan UAT dilakukan dengan 10 responden. Hasil user acceptance test dinilai dengan 5 kategori, yaitu SS (Sangat Sesuai), S (Sesuai), KS (Kurang Sesuai), TS (Tidak Sesuai) dan TJ (Tidak Jawab). Adapun hasil pengujiannya terlihat pada tabel 2.

Tabel 5 Pengujian UAT (User Aceptance Test)

\begin{tabular}{clccccc}
\hline No & \multicolumn{1}{c}{ Pertanyaan } & SS & S & KS & TS & TJ \\
\hline 1 & $\begin{array}{l}\text { Apakah aplikasi chatbot dapat } \\
\text { menjawab pertanyaan? }\end{array}$ & 10 & & - & - & - \\
\hline 2 & $\begin{array}{l}\text { Apakah tampilan aplikasi chatbot } \\
\text { menarik? }\end{array}$ & 1 & 9 & - & - & - \\
\hline 3 & $\begin{array}{l}\text { Apakah aplikasi ini dapat membantu } \\
\text { mencari informasi UNILAK ? }\end{array}$ & 1 & 9 & - & - & - \\
\hline 4 & $\begin{array}{l}\text { Apakah aplikasi dapat membersihkan } \\
\text { chat yang ada ? }\end{array}$ & 10 & & - & - & - \\
\hline 5 & $\begin{array}{l}\text { Apakah jawaban dari chatbot mudah } \\
\text { dipahami? }\end{array}$ & 10 & - & - & - & - \\
\hline 6 & $\begin{array}{l}\text { Apakah aplikasi chatbot efisien dalam } \\
\text { mencari informasi pendaftaran? }\end{array}$ & 1 & 9 & - & - & - \\
\hline
\end{tabular}

Berdasarkan pengujian yang telah dilakukan, penelitian ini memiliki tingkat akurasi 95\% dan lebih tinggi dari penelitian [6] yaitu akurasi $88 \%$. Aplikasi chatbot ini dkembangkan khusus untuk informasi akademik kampus. Aplikasi ini mampu menjawab pertanyaanpertanyaan yang diajukan oleh pengguna, sesuai dengan pengetahuan yang telah diberikan sebelumnya.

\section{Kesimpulan}

Berdasarkan hasil implementasi dan pengujian yang telah dilakukan pada aplikasi chatbot menggunakan metode Artificial Intelligence Markup Language (AIML), maka dapat 
disumpulkan yaitu: Dengan menggunakan metode Artificial Intelligence Markup Language (AIML), aplikasi chatbot mampu menjawab pertanyaan yang diajukan, sesuai dengan pengetahuan yang telah diberikan, Percakapan chatbot dapat dilakukan secara online, dengan menggunakan browser, Aplikasi chatbot yang dikembangkan dapat memberikan informasi mengenai informasi pendaftaran mahasiswa di Universitas Lancang Kuning. Adapun knowledge dari aplikasi chatbot ini adalah alamat kampus, syarat pendaftaran, langkah pendaftaran, program studi, jalur kuliah, berapa biasa kuliah dan cara daftar. Adapun hasil pengujian menggunakan whitebox dan blackbox sebesar 100\%. Pengujian menggunakan UAT sebesar 95\%. Hal ini menunjukkan bahwa aplikasi yang dikembangkan dapat menjawab pertanyaanpertanyaan berdasarkan pengetahuan yang telah diberikan sebelumnya.

\section{Daftar Pustaka}

[1] B. R. Ranoliya, N. Raghuwanshi, and S. Singh, "Chatbot for university related FAQs," 2017 Int. Conf. Adv. Comput. Commun. Informatics, ICACCI 2017, vol. 2017-Janua, pp. 1525-1530, 2017.

[2] D. Toniuc and A. Groza, "Climebot: An argumentative agent for climate change," Proc. 2017 IEEE 13th Int. Conf. Intell. Comput. Commun. Process. ICCP 2017, vol. 2, pp. 6370, 2017.

[3] H. Agus Santoso et al., "Dinus Intelligent Assistance (DINA) Chatbot for University Admission Services," Proc. - 2018 Int. Semin. Appl. Technol. Inf. Commun. Creat. Technol. Hum. Life, iSemantic 2018, pp. 417-423, 2018.

[4] J. Hill, W. Randolph Ford, and I. G. Farreras, "Real conversations with artificial intelligence: A comparison between human-human online conversations and humanchatbot conversations," Comput. Human Behav., vol. 49, pp. 245-250, 2015.

[5] N. N. Khin and K. M. Soe, "University Chatbot using Artificial Intelligence Markup Language," 2020 IEEE Conf. Comput. Appl., pp. 1-5.

[6] B. Rusmarasy, B. Priyambadha, and F. Pradana, "Pengembangan Chat Bot pada CoMa untuk memberikan motivasi kepada pengguna menggunakan AIML," vol. 3, no. 5, pp. 4484-4490, 2019.

[7] E. N. S. C. P and I. Afrianto, "Rancang Bangun Aplikasi Chatbot Informasi Objek Wisata Kota Bandung Dengan Pendekatan Natural Language Processing," J. Ilm. Komput. dan Inform., vol. 4, no. 1, pp. 49-54, 2015.

[8] W. Y. Gang, S. Bo, S. M. Chen, Z. C. Yi, and M. P. Zi, "Chinese intelligent chat robot based on the AIML language," Proc. - 2014 6th Int. Conf. Intell. Human-Machine Syst. Cybern. IHMSC 2014, vol. 1, pp. 367-370, 2014.

[9] T. Nt, "Sebuah ChatBot E-bisnis menggunakan AIML dan LSA," no. September, pp. 2740-2742, 2016.

[10] Y. S. Wijaya, Rahmaddeni, and F. Zoromi, "Chatbot Designing Information Service for New Student Registration Based on AIML and Machine Learning," J. Artif. Intell. Appl., 2020.

[11] R. Wallace, The Elements of AIML Style. 2003.

[12] Y. W. Chandra and S. Suyanto, "Indonesian chatbot of university admission using a question answering system based on sequence-to-sequence model," Procedia Comput. Sci., vol. 157, pp. 367-374, 2019.

[13] N. P. Patel, D. R. Parikh, D. A. Patel, and R. R. Patel, "AI and Web-Based Human-Like Interactive University Chatbot (UNIBOT)," Proc. 3rd Int. Conf. Electron. Commun. Aerosp. Technol. ICECA 2019, pp. 148-150, 2019.

[14] D. P. Y. Ardiana, I. D. M. A. B. Joni, and I. P. A. E. D. Udayana, "Mobile based chatbot application for HIV/AIDS Counseling using Artificial Intelligence Markup Language Approach," J. Phys. Conf. Ser., vol. 1469, no. 1, 2020. 
[15] A. Nursetyo, D. R. I. M. Setiadi, and E. R. Subhiyakto, "Smart chatbot system for ECommerce assitance based on AIML," 2018 Int. Semin. Res. Inf. Technol. Intell. Syst. ISRITI 2018, pp. 641-645, 2018.

\section{(c) (i) (?)}

Digital Zone: Jurnal Teknologi Informasi dan Komunikasi is licensed under a Creative Commons Attribution International (CC BY-SA 4.0) 